\title{
$17: 29707584-29709742$
}

National Cancer Institute

\section{Source}

National Cancer Institute. 17:29707584-29709742. NCI Thesaurus. Code C41858.

Physical location of CCL13_Gene 